Bilbil KASTRATI, Samo UHAN*

\title{
THE EU'S COMMON SECURITY AND DEFENCE POLICY IN THE CASE OF THE EULEX MISSION IN KOSOVO ${ }^{1}$
}

\begin{abstract}
The article considers whether the EU's CSDP missions are a suitable crisis management mechanism for post-conflict situations, along with the EU's relevance in crisis management at all. For this purpose, the EU's biggest CSDP civilian mission EULEX was chosen as a research case study. The research results reveal that EULEX has not implemented its mandate, not met the expectations of security consumers, not made any difference on the ground, and cannot be seen as an example the EU should rely on in its future missions. Further, EULEX shows that CSDP missions suffer from many shortfalls and the EU CFSP from a capability-expectations gap. The article concludes that the EULEX mission does not show the EU's relevance in the crisis management of post-conflict situations.
\end{abstract}

Keywords: EU, CFSP, CSDP, EULEX, crises management, Kosovo

\section{Introduction}

The foreign and security policy objectives of the European Union (EU) include being a global security actor and contributing to "peacekeeping, conflict prevention and strengthening international security" (European Union, 2009: 34). Through the Common Foreign and Security Policy (CFSP), the EU has developed its "policies, capabilities and structures" (Cameron, 2007: 74) and is actively involved around the world in areas of crisis with the goal of supporting the efforts to maintain international peace and security (Ginsberg and Penksa, 2012).

Since 2003, the EU has deployed over 30 missions in the framework of Common Security and Defence Policy (CSDP) whose purpose is to stabilise post-conflict states and societies by providing its share of contribution for international security alone or along with other crisis management actors (European External Action Service, 2018). As such, the EU has transformed its

Bilbil Kastrati, PhD, Bill Clinton Boulevard, BL 5 E4 No. 6, Prishtinë 10000, Republic of Kosovo, bilbil.kastrati@gmail.com; Samo Uhan,PhD, Associate Professor, Faculty of Social Sciences, University of Ljubljana, Slovenia.

1 This article is based on the authors' research for the PhD thesis. 
vision into action as an important security actor, while through the CFSP and CSDP channels the EU's commitments to the exterior and echoes its identity, values, norms and culture (Merlingen and Ostrauskaité, 2008; Toje, 2010; Breuer in Kurowska and Breuer, 2012; Ginsberg and Penksa, 2012; Kaunert and Zwolski, 2013; Larivé, 2014; Costa and Brack, 2014; Shepherd, 2015).

It is critical that the EU can prove it is capable of successfully launching and realising CSDP missions since that signifies the EU is an international crisis management actor (Tardy, 2015). As an economic giant, the EU also raises expectations for its contribution to international security (Kurowska in Merlingen and Ostrauskaite, 2008). Nevertheless, the post-Cold War era and conflicts in the neighbourhood of the Balkans show limits on European capability in security and defence matters (Hill, 1993). This situation in particular, and the EU's ambition to become a global security actor (Council of the European Union, 2003), have driven the Europeans' hasty engagement to develop the necessary security and defence capabilities (Cameron, 2007). However, this fast pace and the considerable number of CSDP missions deployed question their impact and the lasting change they actually produce in post-conflict states and societies. Therefore, according to Tardy (2015), the performance of the EU's CSDP should be assessed according to the three elements of: efficiency in delivering its mandate, meeting the expectations, and its contribution to international security. The general assessment is that both the civilian and military CSDP missions deployed thus far show that the EU favours small-scale missions in response to issues that are low on the international political agenda, inefficient, driven by member states' interests, motivated by political visibility and the perceived need for the Union to provide a response to lack of security (Toje, 2010). Moreover, the theories on the CSDP's drivers ${ }^{2}$ indicate that the EU mem-

\footnotetext{
2 The neorealist stance driving the CSDP missions is the structure and distribution of power in world politics; the EU's impact on member states' political, economic and other interests; and the EU's impact on the decisions of member states' foreign policy acting in the Union's context. The theory explains that material interests are the driving force in the emergence of the CSDP missions and the decisions are based on cost-benefit calculations where the strongest EU member states will carry the costs only in cases which can strengthen their influence. In this respect, the strongest EU member states shape and influence the external environment according to their interests (see Ginsberg and Penksa, 2012; Jacek, 2014). Rational choice institutionalists argue that an international institution like the EU is chosen to benefit its principals, the EU member states. Member states then delegate their authority to the Council and the Commission to execute their decisions (see Dyson and Konstadinides, 2013). While the neorealist and institutionalist points of view focus on the state and international institutional actors in the search for rational interests, the perspective of social constructivism is that there cannot be an EU foreign policy or CSDP without a European identity. The European identity is embedded in norms, values and culture that inform and stimulate the EU'S CSDP missions. The theory underlines the importance of ideas and identities, and how these factors influence and shape the understanding and response of the member states to specific events. Therefore, the social construction of identities leads to roles and responsibilities of the EU member states in international security (see Ginsberg and Penksa, 2012; Dyson in Cladi and Locatelli, 2016).
} 
ber states choose to deploy CSDP missions not so much to provide benefits for the conflict-affected society or state, but based on a calculation of the risks and costs, missions which are close to home, allow for learning, are consensus-based, and give the EU the possibility to show its presence on the international stage (Tardy, 2015).

This article presents research on the achievements of the European Union Rule of Law Mission in Kosovo (EULEX) ${ }^{3}$ from the viewpoint of the security consumers and results achieved on the ground (Kosovo) between 2008 and 2018. EULEX is chosen as a case study since it is the biggest and most extensive civilian CSDP mission to date and was used as a sample to assess the CSDP's strengths and weaknesses as a tool of the EU, so as to serve as an indicator of the EU's development in crisis management. The article answers the question of whether the CSDP missions are a suitable crisis management mechanism for post-conflict situations.

\section{Research problem}

Kosovo reached prominence in 1999 when NATO bombed Serbia for 78 days to stop the fighting of the Serbian Security Forces and the Kosovo Liberation Army ${ }^{4}$. However, the 'Kosovo problem' started much earlier in the context of the Ottoman Empire's dissolution ${ }^{5}$ in 1912, its occupation by Serbia ${ }^{6}$, and the recognition of these territories as spoils of war at the Conference of Ambassadors convened in London ${ }^{7}$ in late December 1912 (Malcolm, 1998). More than eight decades later, Kosovo once again became a victim of a brutal war (1997-1999) waged by Serbia that marked the collapse of Yugoslavia. NATO's intervention in Kosovo in 1999 opened the way for the deployment of the United Nations (UN) ${ }^{8}$ and other international organisations (Schmitt, 2012), and 9 years later to the independence

\footnotetext{
3 European Union Rule of Law Mission in Kosovo, accessible at https://www.eulex-kosovo.eu/.

4 The Kosovo Liberation Army's attacks on Serbian police and military posts inflicted harsh and disproportionate use of force by the Serbian government (see Mahncke in Monar and Wessels, 2001).

5 At the beginning of the 20th century, territories inhabited by Albanians included today's Albania, Kosovo and parts of western North Macedonia, northern Greece, south-east Montenegro and southern Serbia, which were administered by the Ottoman Empire until 1912 (see Schmitt, 2012).

6 The Serbian army advanced in present-day Kosovo territories in October 1912 and finished its conquests by the end of the month (see Malcolm, 1998).

7 The Great Powers of the time - Austria-Hungary, Great Britain, France, Germany, Italy and Russia - discussed sharing the liberated (occupied) territories from the Ottoman Empire. These discus sions included the territories inhabited by Albanians as well. The Austria-Hungary was advocating for an independent Albanian state that would include all lands inhabited by Albanians. However, there was strong opposition from Russia (Serbia's supporter) arguing against this idea; therefore, it was agreed at this conference that the cities and territories which today comprise Kosovo would be part of Serbia.

8 United Nations Mission in Kosovo - UNMIK, accessible at https://unmik.unmissions.org/.
} 
of Kosovo9 from Serbia (Bilefsky, 2008). The EU has played an important role in the international efforts to rebuild post-conflict Kosovo since $1999^{10}$. Still, much remains to be done with respect to Kosovo's state-building and hence the deployment of the EU's CSDP mission EULEX to strengthen the rule of law there (Zupančič et al., 2018).

EULEX was deployed in Kosovo within the EU's crisis management framework (Tardy, 2015). Crisis management is an important tool the EU uses to achieve its foreign security and policy objectives. According to Prezelj (2005: 35-36), "crisis management is defined in a non-traditionalist sense as more or less organized activities aimed at resolving or managing any crisis (a) at the appropriate level and (b) in the corresponding dimension (c) before, during and after the crisis".

Crisis management is a security-centred activity in the sense that the crises dealt with have a security dimension, even though the security measures selected might go beyond the traditional ones. In practice, the most prominent crisis management activities employed are security, conflict prevention, the rule of law, and security sector reform. These measures are about responding to threats that are not direct and immediate, and about the projection of security outside of the EU area by assisting in the stabilisation of fragile regions and states that might threaten or destabilise European society directly. Crisis management missions are inherently complex activities as they depend on the support of the EU member states, both political support and material resources. The member states may for different motivations decide to contribute to achieve their foreign policy, economic interests, solidarity with the allies; rather than to support a country in crisis. Further, some missions are driven by external factors like the need for the EU's visibility, to foster the influence of a member state in a region, or to respond to public pressure concerning a humanitarian emergency (Tardy, 2015).

The EULEX mission in Kosovo was established on 4 February 2008 with Council Joint Action 2008/124/CFSP (Official Journal of the European Union, 2008). The mission aims to assist the Kosovo law enforcement agencies in reinforcing the multi-ethnic justice system, police and customs service. The core functions of EULEX are to monitor, mentor and advise (MMA) Kosovo's rule-of-law institutions in establishing institutional practices that

9 Russia, a major ally of Serbia, backed by China and some European countries (Spain, Romania, Cyprus, Slovakia and Greece) disputed the legality of the unilateral declaration of Kosovo's independence and warned that this case might establish a dangerous precedent for the international order.

10 The EU is by far the leading donor assisting Kosovo. According to some estimates, since 1999 Kosovo has received more than EUR 2.3 billion in EU assistance and around EUR 1 billion in support of the international presence (see Venner, 2012). Whereas at the beginning the EU's focus was on emergency relief actions and reconstruction, the EU now concentrates on the promotion of Kosovo's society, its viable economic development and its European future. Further, on 1 April 2016 the EU signed the Stabilisation and Association Agreement (SAA) with Kosovo (see Council of the European Union, 2016). 
support the country's overall democratisation. Besides, EULEX maintains executive functions concerning the investigation and prosecution of serious and sensitive crimes in the areas of war crime, organised crime and high-level corruption, as well as property and privatisation cases. EULEX is in many respects unique and indicates the EU's level of ambition with the CSDP civilian crisis management missions. Four distinct features single the EULEX mission out from all others to date. First, the mission's size, with EULEX having included around 3,000 staff (international and local). Second, EULEX's mandate is very large, encompassing a fully integrated rule-of-law mission spanning the fields of justice, police and customs, with an executive mandate. Third, EULEX has centralised a whole range of important horizontal tasks at its headquarters in Prishtina, such as programming, procurement, personnel etc. Fourth, EULEX is distinguished by its thorough programmatic approach devised according to the stated aims and objectives of the mandate. Further, EULEX is not simply the largest and one of the longestrunning CSDP civilian missions, but one of the most expensive.

Zupančič and Pejič (2018) state that, from the start, EULEX has been an ambitious mission whose task has been to support the rule-of-law services in Kosovo and fight high-level crime and corruption. EULEX promised a functional and efficient rule-of-law system in Kosovo that would result in a well-functioning democracy and sustainable peace. These objectives stated by the EU with respect to EULEX may be considered as the EU's projections for further engagement in the international arena in a post-conflict environment alongside other international security actors. Of course, this will very much depend on the success of EULEX itself and how external actors assess it. An important observation in this regard is made by Baussner and Ferhatovič (in Merlingen and Ostrauskaité, 2008: 186) who claim that the CSDP missions serve the "Union's efforts to brand itself as a distinct actor in international security affairs, including peacebuilding and post-conflict stabilization, are more for its purpose than for the host society or, put differently, security consumers". As such, it is important to know if EULEX was deployed in Kosovo for the purpose of the EU accomplishing its political and other interests or to improve the rule of law and security in general. If the results of this research show that EULEX has been successful in establishing a functioning and sustainable rule of law, this would provide evidence that the EU has put EULEX in place to support the rule-of-law system in Kosovo. Alternatively, the absence of clear results may suggest the EU has deployed EULEX more for its own interests. While assessing the work of the EULEX mission in Kosovo in relation to the rule of law, an important benchmark is the European Commission country report for Kosovo ${ }^{11}$. The report

11 See European Commission, 2020. 
is issued on an annual basis and monitors Kosovo's progress in the area of the rule of law, and other issues. Since the report is commissioned by an EU institution, its findings provide important and reliable information concerning the results of the EULEX mission in Kosovo.

In sum, EULEX has an extensive mandate and the fact that this mission was projected to be the flagship of the EU's CSDP means it may serve as a good case for evaluating the EU's relevance when it comes to crisis management.

On this basis, the following key research question was formulated:

Have the results of the EULEX mission in Kosovo in implementing its mandate, met the expectations of the security consumers, is there any real difference on the ground, and is EULEX an example of good practice that shows the relevance of the EU'S CSDP in crisis management?

In answering the initial research question, we considered four sub-questions:

a. Has the EULEX mission in Kosovo implemented its mandate?

b. Have the expectations of the security consumers in Kosovo been met by EULEX?

c. Has EULEX made any real difference on the ground with regard to an improved rule of law in Kosovo?

204 d. Is the EULEX mission in Kosovo an example of good practice the EU should adopt in its future interventions?

\section{Research methodology}

This research was based on the constructivist paradigm, which hypothesises that learning is a continuous constructive process and that the learner is an information constructor. Cohen and Manion (1994) posit that the constructivist research approach is founded on understanding the world of human experience. Moreover, the research design for this study was in line with the principle of methodological triangulation, meaning that different methodologies were used to collect the data on which this research is based, thereby strengthening its reliability and internal validity (Creswell, 2003). The case study was chosen as the most suitable research strategy for this research. According to Gerring (2007), a case study is an intensive study of a single case with the purpose of shedding light on a large group of cases. He considers that in-depth knowledge of an individual case is more helpful than broad knowledge about a considerable number of cases. Therefore, he concludes that we understand better the whole when we are focussing on the main part. The research for this study is conducted from the prism of the consumers of security (Kosovo citizens); however, to ensure the objectivity of the study and avoid bias, the perspectives of experts from Kosovar Civil Society representatives (CS), officials at Kosovar institutions 
(KI), and EULEX officials were also considered. The sample population for this research was citizens of Kosovo $(\mathrm{N}=50)^{12}$, CS representatives $(\mathrm{N}=5)^{13}$, KI officials $(\mathrm{N}=5)^{14}$ and EULEX officials $(\mathrm{N}=5)^{15}$. The selection criteria for the research participants, the sample of Kosovar citizens, were first that they were at least 18 years old at the time EULEX had been deployed in Kosovo, and second that they were willing and able to answer the set questions. The selection of the experts (elite) sample first considered whether they have either worked for EULEX, been KI officials who have cooperated with EULEX, or been CS representatives who have monitored, analysed or reported about EULEX's work. Second, that they were willing and able to answer the set questions.

The sample of Kosovo citizens ${ }^{16}$ was interviewed to ensure a comprehensive view from the field of the results of EULEX as well as to avoid an elitist approach to the research, investigating their perceptions and beliefs as consumers of the rule-of-law assistance provided by EULEX. The reason for choosing to interview the elite is that EULEX officials are the key providers of security in terms of the rule-of-law through EULEX in Kosovo and hold important insights that may inform on EULEX's work and share their thoughts on its strengths and weaknesses. The KI officials are the recipients of the security/rule of law support of EULEX and thus can inform and share their perceptions on the success/failure of EULEX in implementing its mandate. Finally, the CS representatives were selected for the research because they are involved and influence the debate on EULEX, while also monitoring and reporting on its work and results. Most interviews were conducted face-to-face ${ }^{17}$, with the rest by telephone ${ }^{18}$. The data collection period lasted from 15 September 2017 until 25 May 2018. Separate questionnaires were developed for the interviewed sample of Kosovo citizens ${ }^{19}$ and experts ${ }^{20}$. The interviews were recorded and transcribed, saved in an Excel file and coded. Further, relevant documents of the EU institutions concerning the research topic were carefully read and analysed to understand and correctly

1241 men and 9 women, of whom 34 from the Kosovo Albanian community, 7 the Kosovo Serbian community, 6 the Kosovo Turkish community, 2 the Kosovo Bosnian community, and 1 the Kosovo Roma community

133 men and 2 women, Kosovar Albanians

144 men and 1 woman, Kosovar Albanians

154 men and 1 woman, 2 British citizens, 1 Spanish citizen and 2 Kosovo Albanians

16 Ten citizens from each of the five Kosovo regions: Prishtinë, Prizren, Pejë, Mitrovicë and Gjilan

1754 interviews

1811 interviews

19 The questionnaire for the citizens was composed of 13 questions and aimed to find out the opinions and perceptions of the citizens about EULEX's performance.

20 The questionnaire for experts contained 25 questions, and sought to cross-examine the selected experts on issues related to the mandate, challenges faced, opportunities and missed chances of EULEX and the $E U$. 
interpret the meaning and aims of the EU with EULEX. In addition, it is noted the author of this article has been in the field since EULEX's inception in 2008 and was a close observer of its work until 2018.

\section{Results}

Implementing the mandate, particularly its tasks, is an EU CSDP mission's main goal and an indicator of the impact on the given state and society where the intervention takes place. Therefore, in this part, we focus on assessing whether EULEX has implemented its tasks ${ }^{21}$ based on findings of the research interviews, EU documents, the author's own observations, media articles, and reports. This will create the bases for answering the research questions.

The first task of EULEX was to $\mathrm{MMA}^{22}$ Kosovo rule-of-law institutions. The responses of the interviewed sample of experts from CS, the KI and the EULEX officials show that EULEX has partly completed this task. The interviewed sample consider that EULEX was particularly successful in the first 3-4 years of its mandate in support of Kosovo institutions with advice on policy and legislative reform, the process of Kosovo-EU visa liberalisation, public security, customs and border management. However, later on, EULEX's results seemed to have fallen short, even though the interviewees believe EULEX is continuing to make an effort. As such, they assess that EULEX has partially implemented this task.

Further, EULEX was tasked with maintaining and promoting the rule of law, public order and security in Kosovo ${ }^{23}$. Generally, according to the observations of the author of this article, the public in Kosovo is not aware of EULEX's contribution here. The interviewed sample of experts from CS, the KI and the EULEX officials hold diverging opinions on EULEX's achievements in this regard. They emphasise that EULEX has failed to ensure public order, security and establish the rule of law in northern Kosovo ${ }^{24}$; yet, else-

21 Official Journal of the European Union, 2008, Article 3, op. cit.

22 MMA tasks of EULEX had extensive horizontal and vertical involvement in Kosovo's rule of law institutions. Its role to monitor, mentor, advice, but also to build capacities and coordinate, gives EULEX a central position in the entire justice and law enforcement system from where it can influence and foster reform of the rule of law in Kosovo. EULEX officials were sitting side by side with their Kosovo colleagues in ministries, courts, the prosecutor's office, police stations, detention centres and customs offices.

23 This task included many activities of EULEX intended to increase public awareness of the rule of law in Kosovo and at the same time ensure its maintenance. Likewise, EULEX based on its mandate has had responsibilities for public order and is the second security responder, with Kosovo Police being the first and KFOR (NATO) the third responder (hard security).

24 Northern Kosovo is composed of the four municipalities of Mitrovica North, Zvečan, Leposavič and Zubin Potok, mainly inhabited by the Kosovo Serb community that opposes the independence of Kosovo and the authority of the Kosovo Government. 
where in Kosovo, they say EULEX has brought a sense of trust and hope for positive changes and that EULEX could not have performed better in the given environment and circumstances in which it has operated. Thus, the interviews with the experts allow the conclusion that EULEX has been partly successful in this respect.

The other major task of EULEX has been to prevent political interference in Kosovo's rule-of-law institutions ${ }^{25}$. This task was assigned to EULEX since it is widely perceived by the Kosovo public that the rule-of-law institutions in Kosovo are highly politicised (see Bajrami 2011; Kosovo Law Institute, 2018; European Commission, 2018). The dominant opinion of the interviewed sample of Kosovo citizens and interviewed sample of experts from CS, the $\mathrm{KI}$ and the EULEX officials is that EULEX has failed in this task and that political interference has even increased following the deployment of EULEX. These interviewees state that political interference in Kosovo's rule-of-law institutions is mentioned in all European Commission country reports for Kosovo $^{26}$ as a concerning issue. Further, they consider that when the EULEX mandate was being designed it was a mistake to assign this task to EULEX because it was wishful thinking that the EULEX could ever have performed such a task. In their view, perhaps the EU's Special Representative Office in Kosovo ${ }^{27}$ would have been better suited to this task.

Moreover, the core task of EULEX has been the investigation, prosecution, adjudication and enforcement of criminal cases in Kosovo ${ }^{28}$. The primary focus of Kosovo citizens, CS, KI and EULEX has presumably been successful implementation of this task. Unfortunately, the big expectations led to big disappointment (Bajrami, 2011). The majority of the interviewed samples of Kosovo citizens and experts from CS, the KI and the EULEX officials agree that EULEX has failed in this sense. They believe that the volume of actions for this task assigned to EULEX was beyond its capacities to perform such duties and it was a premature decision of the EU to give an executive mandate to the CSDP civilian mission. Specifically, they mentioned that EULEX has not had sufficient investigators, analysts, judges and prosecutors to perform this task. EULEX has thus failed in fighting crime and corruption, and other criminal cases like war crimes.

25 The EULEX mission was mandated to ensure that the rule-of-law institutions in Kosovo work free from political interference.

${ }^{26}$ European Commission, 2020 op. cit.

27 European Union Special Representative in Kosovo, accessible at https://eeas.europa.eu/delegations/ kosovo_en.

28 The investigation, prosecution, adjudication and enforcement of cases of war crimes, terrorism, organised crime, corruption, inter-ethnic crimes, financial/economic crimes and other serious crimes is only one of the nine tasks with which EULEX has been mandated with; however, this task had the main focus and expectations from the Kosovo public, but at the same time it has been the biggest opportunity for EULEX to excel. 
Another important task of the EULEX mandate has been to strengthen cooperation with and coordination of the judicial process, especially in the area of organised crime ${ }^{29}$. Cooperation and coordination in the field of organised crime are very specific and important, not only because it takes place in Kosovo and harms Kosovar society, but because organised crime has a regional impact and stretches all the way to the EU ${ }^{30}$. Therefore, this task of EULEX was central to achieving the goal of strengthening the rule of law in Kosovo as well as of wider European security. One major problem identified by the interviewed sample of experts from CS, the KI and the EULEX officials was that the EULEX structures of police, prosecution and judiciary have not cooperated with the Kosovar police, prosecutors and judges; in a way, they have acted separately, despite the fact they should be working together ${ }^{31}$. The reason for this outcome was the absence of trust between EULEX and Kosovo institutions. This relationship between EULEX and Kosovo's institutions has undermined the results of fighting organized crime.

In addition, EULEX was tasked to investigate financial, fraud and corruption cases associated with money laundering and other financial crimes ${ }^{32}$ The author of this article has observed in the last decade, as an example, that construction has flourished in the main centres of Kosovo where entire neighbourhoods have been constructed, largely disproportionate to the income of the citizens of Kosovo and their purchasing power ${ }^{33}$. Despite the big flow of money into Kosovo, far in excess of the Kosovo state's economic capacities and development, no case of this nature has been resolved by EULEX in the decade of its work. The majority of the interviewed sample of experts from CS, the KI and the EULEX officials consider this is due to the protection the criminal groups enjoy from the key political figures in Kosovo. Likewise, the interviewed sample of Kosovo citizens believes that evidence of criminal activities has been destroyed and witnesses threatened, preventing EULEX from successfully completing this task. Therefore, the period after 2010 has been denoted by a constant drop in the public's trust in EULEX (UNDP, 2013).

29 The work of EULEX was of course aimed primarily at protecting the Kosovar state and society, while also thwarting criminal activities that originate from third countries and through Kosovo affect the EU and its citizens.

30 See European Commission, 2014

31 Interview, Prishtinë, 12 April 2018.

32 EULEX has had to fight money laundering and organised crime, which are associated with the financial transactions where EULEX has been tasked to investigate the links between corruption, fraud and financial crime and, when appropriate, to prosecute, adjudicate and enforce these cases.

33 The big flow of money, aside from the remittances sent from the diaspora, cannot be justified, considering the poor economic development of Kosovo, thus raising suspicious concerning criminal activities and money laundering. 
Moreover, EULEX was tasked specifically to support Kosovo's rule-oflaw institutions in fighting corruption ${ }^{34}$. In so doing, they were supposed to assist the Kosovo Anti-Corruption Agency in drafting and implementing the Anti-Corruption Strategy and Action Plan. The interviewed sample of experts from CS, the KI and the EULEX officials stated that the absence of any record or a tangible result indicates that EULEX has only modestly supported the Kosovo Anti-Corruption Agency in this regard. Some interviewees who were members of the working group for drafting the Strategy and Action Plan stated that EULEX's contribution consisted of organising workshops for participants and less by way of any real substance. They believe EULEX's support should have entailed less paying for lunches and refreshments at the workshops and focussed more on the substance in terms of providing policy advice and sharing best anti-corruption practices.

Alongside its tasks of supporting Kosovo's rule-of-law institutions, EULEX has had to respect international human rights standards and ensure gender equality in its activities. The majority of the interviewed sample of experts from CS, the KI and the EULEX officials consider there is no clear evidence that EULEX has accomplished this task. Moreover, they claim that EULEX has promoted the international standards concerning human rights and gender mainstreaming, yet never applied them in practice. For example, there have been lengthy procedures in the courts whereby EULEX has violated human rights since, as the Criminal Code of Kosovo requires the expedient resolution of cases. Further, there have been issues with gender equality since $80 \%$ of EULEX's employees have been male. Experts claim that EULEX has intercepted Kosovar citizens' telephone calls, without ever informing them of their rights.

Furthermore, EULEX provided support for the EU-facilitated dialogue between Prishtina and Belgrade ${ }^{35}$. This task of EULEX was subject to lively debates especially from CS in Kosovo on the aims and appropriateness of this task for EULEX. Nevertheless, despite the criticism of this task and the

34 Fighting corruption is a priority of the Kosovo state and society. In this endeavour, Kosovo is supported by many international organisations and different projects. Likewise, EULEX as a rule-of-law mission in Kosovo has had to have a role and contribute to the implementation of Kosovo's policies against corruption.

35 This task foresaw EULEX providing technical support in implementation of the agreements reached in Brussels between the parties. These agreements included the agreement on civil registry books that were returned from Serbia to Kosovo and the establishment of a reliable civil registry in Kosovo through EULEX MMA assistance. Further, EULEX supported the implementation of the Integrated Border Management (IBM) through the establishment of crossing points between Kosovo and Serbia to improve the flow of traffic and collect custom revenues at the crossing points. Also, EULEX has supported the implementation of the Freedom of Movement Agreement, capacity-building of the Kosovo Police to enhance the security and protection of Kosovo's religious and cultural sites. Further, the integration of the former Serbian police and Civilian Protection staff into Kosovo Police and other Kosovo institutions, and the integration of Serbian judiciary authorities into Kosovo's unified justice system (see EULEX, 2018). 
concerns raised, regarding whether rule-of-law mission should have been involved in the facilitation of political agreements, the majority of the interviewed sample of experts from CS, the KI and the EULEX officials assessed EULEX's role as constructive and positive. One may hence conclude that EULEX has implemented this task successfully.

Finally, EULEX has had a challenging task of a witness-protection programme ${ }^{36}$. Generally, the interviewed sample of experts from CS, the KI and the EULEX officials did not have much information on this task of EULEX. However, a senior official of the Kosovo Police responsible for investigation interviewed ${ }^{37}$ for this article stated that "EULEX has not been successful in providing witness protection. The results of the witness protection programme have not led to any case being resolved or individuals sentenced". Further, in a submission to the parliament by former British Minister for Europe, Mr David Lidington, he stated that the "witness support unit and justice component [of EULEX] suffers from a shortage of suitable candidates; and that hampers EULEX's ability to proceed with investigations and prosecutions and could impact on its investigations" (House of Lords, 2014: 31). In addition, as observed by the author, people in Kosovo speak about witnesses or members of their families who have been threatened not to testify in courts against powerful individuals in Kosovo associated with crime and politics. There have also been reports that key witnesses in major trials were murdered, including some in EULEX's witness protection programme, the major one being the case of 'witness X' (Bytyçi, 2011; Bajrami, 2011). This does not permit the conclusion that EULEX has implemented this task.

From the insights provided above, the answer to sub-question (a): Has the EULEX mission in Kosovo implemented its mandate, is negative. Only one task of the mandate has been implemented successfully and two partly, while all the other tasks were revealed by this research not to have been implemented. This then confirms the statement by Capussela (2015), an EU official assigned to Kosovo, who stated that EULEX stands no chances of meeting the expectations concerning the implementation of its mandate.

Kosovars, the security consumers of EULEX's support, have had high expectations of this mission. Frustrated with the enervated UN mission (UNMIK) after almost 10 years since being established, Kosovars were seeking an EU mission able to support Kosovo in strengthening the rule of law. In the Kosovars' understanding, EULEX support in strengthening the rule of law in Kosovo meant capacity-building of the Kosovo rule-of-law institutions and fighting crime and corruption associated with high-profile

36 EULEX's witness protection programme is intended to provide security to individuals who have witnessed different crimes during and after the conflict in Kosovo, with an emphasis on war crimes, organised crime and corruption.

37 Interview, Prishtinë, 27 April 2018. 
politicians. At the beginning of the mandate in 2008, EULEX officials' promises to uproot crime and corruption in Kosovo further fuelled these expectations of Kosovars (Palokaj, 2010; Bajrami, 2011). Of course, this gave hope to Kosovars who were eagerly looking forward to an effective and efficient rule of law in Kosovo. In 2008, nobody in Kosovo held even the slightest of doubts that EULEX would not achieve its goals. However, it seems that EULEX's statements about a rigorous fight against the high-level political elites involved in crime and corruption, the 'Big Fish', have not been translated into action (Bajrami, 2011). The majority of the interviewed sample of Kosovo citizens stated that EULEX has not met their expectations of an improved rule of law in Kosovo. Most of the interviewed sample of experts from CS and KI agree with the interviewed sample of Kosovo citizens; although, the majority of the interviewed sample of EULEX officials consider that Kosovars' expectations of EULEX were higher than what EULEX could actually deliver.

Nevertheless, considering that the research for this article was conducted from the perspective of security consumers (Kosovo citizens), the answer to sub-question (b): Have the expectations of the security consumers in Kosovo been met by EULEX, is negative. Based on the responses of the interviewed sample of security consumers in Kosovo and drawing from the answer to sub-question (a) on the level of implementation of the EULEX mandate, we can safely conclude that EULEX has not met the expectations of Kosovars. Moreover, this state of affairs confirms the suspicions of Baussner and Ferhatovič (in Merlingen and Ostrauskaité, 2008), who claim that CSDP missions serve more the EU's interests than those of the security consumers.

In addition, well-established, functioning and independent rule-of-law institutions of Kosovo, working in harmony with international standards and best practices, was the goal of EULEX. Sustainable Kosovar rule-of-law institutions able to function independently and professionally without further international support would amount to a noticeable and real difference in Kosovo and be a legacy of EULEX.

The answers provided by the majority of the interviewed sample of Kosovar citizens' reveal that EULEX has not made any real difference by way of improving the rule of law in Kosovo. The levels of crime and corruption have not fallen since the deployment of EULEX. Further, war crime cases have not been resolved, cases of organised crime associated with money laundering not addressed, political influence in the rule-of-law institutions has remained the same, security has not been improved and, finally, EULEX has not managed to establish the rule of law across the entire territory of Kosovo. Moreover, the majority of the interviewed sample of experts from $\mathrm{CS}$, the KI and the EULEX officials consider that there is no noticeable or real difference in Kosovo in terms of better functioning rule-of-law institutions 
after a decade of EULEX's presence. To quote one interviewee: "EULEX has been a waste of time and money"38.

Hence, the answer to sub-question (c): Has EULEX made any real difference on the ground with regard to an improved rule of law in Kosovo, is negative. The author of the article can also confirm that EULEX's engagement has not produced the expected results here. This fact is further confirmed by the European Commission regular country reports for Kosovo ${ }^{39}$ since 2014 which state that Kosovo is in "an early stage" in its fight against corruption and organised crime, and in developing a well-functioning judiciary system, and other sources (see Bytyçi, 2018).

The EU's CSDP intervention through EULEX in Kosovo, a small country in Europe's neighbourhood, is a test showing the maturity of the CSDP, the EU's capabilities as well as the cohesion of the EU member states. As such, this mission was supposed to set an example of the EU's abilities in implementing CSDP missions. EULEX has had all the means, human and financial, to meet its ends, at least in theory. Achieving its goals in Kosovo through EULEX would be evidence of the EU's capability and act as an incentive to deliver security and stabilisation in post-conflict settings elsewhere (Zupančič and Pejič, 2018). This would further improve the EU's image as an international security actor in crisis management. However, the biggest and most costly EU CSDP mission seems not to have convinced the interviewed sample of Kosovo citizens that EULEX has been up to the job. The majority of these interviewees considers that EULEX is not a model the EU should adopt as an example in its future CSDP missions. In the same vein, the majority of the interviewed sample of experts from CS, the KI and the EULEX officials generally disapproved of the idea that EULEX could be used as a model in future CSDP missions. They believe that EULEX is instead a perfect example of a failure, an example of a rule-of-law mission that the EU should not deploy in the future.

Therefore, the answer to sub-question (d): Is the EULEX mission in Kosovo an example of good practice the EU should adopt in its future interventions, is negative.

To conclude, all of the insights and knowledge generated by determining answers to the four sub-questions above have helped explain the assessment of EULEX's results, which establish the basis for ascertaining the EU CSDP's relevance in crisis management. As one of the biggest and most extensive CSDP missions, EULEX has been instrumental in providing this assessment. Accordingly, the answer to the key research question: Have the results of the EULEX mission in Kosovo in implementing its mandate, met

\footnotetext{
38 Interview, Prishtinë, 12 April 2018.

39 European Commission, 2020, op. cit.
} 
the expectations of the security consumers, is there any real difference on the ground, and is EULEX an example of good practice that shows the relevance of the EU'S CSDP in crisis management, is positive.

Sub-question (a) showed that EULEX has not implemented its mandate. This raises a question for the EU's CSDP crisis management planners concerning whether the mandate assigned to EULEX has been far more extensive than its capacities have been. This allows the conclusion that assigning these complex tasks to EULEX, especially the executive mandate, was a premature decision.

In addition, in answering sub-question (b) it was established that EULEX has not met the expectations of the security consumers. It seems the EU's CSDP planners took several wrong steps with EULEX. Besides the extensive mandate mentioned earlier, there was no proper planning of an information and communication strategy, promising things that could not be delivered like the fight against the political elite, the 'Big Fish', involved in crime and corruption in Kosovo. As such, the EU's CSDP planners have much to learn from EULEX with respect to its next crisis management missions. The timely and adequate development of an information and communication strategy for security consumers would have ensured that they hold realistic expectations of the CSDP mission.

In theory, at least, the EU's CSDP interventions should introduce some positive and lasting changes for the state and society in which its missions are deployed. Ten years after EULEX's deployment in Kosovo, hardly any positive or meaningful change can be observed, as confirmed by sub-question (c). Once again, here mention is made of EULEX's extensive mandate and the information and communication strategy. Had the mandate been more focused and resources concentrated on a specific task, for example, support for the judiciary; and with a cleverer information and communication strategy, perhaps EULEX would today have better chances of having made a real impact on Kosovo's rule-of-law system. Namely, this should be a lesson for future CSDP crisis management missions: to focus its mandate on one particular task and to succeed with it, rather than extending to many tasks and risking failure altogether.

The EU builds on the knowledge and experience that emerge from its past missions and makes efforts to bridge the identified gaps, ensure more resources, plan and equip better future CSDP missions (Dari et al., 2012). While EULEX can be used to analyse all of the shortcomings of this mission and generate knowledge for future missions, the EULEX mission as such should not be used as a model, as was established in sub-question (d). Another lesson for the EU is that the intervention in Europe's neighbourhood in an area well known by the EU, a small country (Kosovo) with a small population, may have created the impression that this EULEX intervention 
would have been straightforward. However, most probably, the EU overlooked its capacities and structural problems such as human resources or strategic planning and thereby did not meet the intended goals. Therefore, no future mission should be identified or understood as a flagship of the EU's CSDP before concrete and reliable results have been achieved.

The research conducted for this article has thereby demonstrated that an assessment of the results of implementing the CSDP mission's mandate, meeting the security consumers' expectations, making a real difference on the ground and setting an example for future CSDP missions are required to show the relevance of the EU's CSDP in crisis management.

Finally, drawing from the research findings, discussions and arguments presented above, we may answer the article's central research question: Are the EU's CSDP missions a suitable crisis management mechanism for postconflict situations? The EULEX case study has shown that the EU's CSDP missions are perceived positively and generate hope and expectations for post-conflict states and societies. This means that security consumers warmly welcome the CSDP missions with the hope of overcoming the consequences of the conflict and stabilising the state and society. The EU is a strong brand mainly due its trade and financial instruments, yet we are una-

214 ble to claim this for the EU CSDP, at least not at the present. The EU through EULEX as demonstrated in this article has not achieved the intended results to remedy the outcomes of the crisis. The rule of law issue has been a concern for Kosovo ever since the conflict ended in 1999 and remained so in 2018. In terms of restraining the spread of the crisis' consequences, it was mentioned that EULEX has generally failed to address or prevent criminal cases of suspicious money laundering in Kosovo whose effects extend beyond its borders. The lack of EULEX's results in addressing these criminal activities is not only undermining the state of Kosovo, but providing for its spread to European countries. Further, the absence of any real impact on the rule-of-law institutions of Kosovo has not created an environment allowing for a longer-term solution. Hence, an assessment of the strengths and weaknesses of the EULEX mission does not confirm the EU's relevance in the area of crisis management.

\section{Conclusion}

In its attempt to play a role in international security along with other crises management actors, the EU has developed policies, structures and capacities, and is actively involved around the world in crisis areas to support peace and post-conflict stabilisation. The EU thereby provides its share of responsibility to international peace and security and makes efforts to ease conflicting situations that could affect security in the EU. 
The historical account of the EU's interventions in the CSDP framework may be seen as a great achievement in the sense that the EU has deployed over 30 CSDP missions and operations in less than two decades. Yet, the results by way of ensuring peace and security, and stabilising post-conflict states and societies, are thus far not that impressive. This, of course, depends on the perspective from which the EU's achievements are assessed. While perhaps the EU institutions or members states view the mere deployment of a CSDP mission as a success; this might not be seen in the same way by the security consumers or post-conflict states, which expect the EU's CSDP missions support to stabilise the state and society. The EULEX mission in Kosovo is a case in point. This CSDP mission has not achieved the expected results of an improved rule of law in Kosovo. EULEX was deployed on the European continent, in a state well known to the Europeans. As such, it was expected that EULEX would achieve its goals and excel as a crisis management actor. This view is based on the fact that EULEX was deployed almost a decade after the conflict in Kosovo, when most of major work on institutional building, the rule of law, and post-conflict reconstruction was completed by other crisis management actors. Therefore, EULEX was deployed in a fairly stabilised context and its role was only to further strengthen the rule-of-law institutions of Kosovo, compliant with international standards and EU best practices.

Still, the EULEX case study displays several shortfalls, which evidence the weaknesses of the EU CSDP. Research for this article show the results of the EULEX mission in Kosovo have been disappointing, even though one task of the mission was completed successfully and two partly. Agreeing with this statement are the majority of the interviewed sample of Kosovo citizens, the interviewed sample of experts from CS, the KI and the EULEX officials, the author of this article, as also confirmed by different local and international reports.

With its extensive mandate and executive powers, EULEX had unlimited access to Kosovo rule-of-law institutions, in some cases even exclusivity. From this perspective and with the strong support of Kosovar citizens, it was quite reasonable to believe that EULEX would achieve positive results. Unfortunately, this has not been the case. This research shows that EULEX has for the most part not even formally implemented its mandate. Moreover, EULEX's intervention has not created an environment for a long-term solution for the rule-of-law system of Kosovo.

In addition, the EULEX case study reveals that CSDP missions suffer from many problems like human resources, information and communication strategies, extensive mandates, and a poor witness protection programme. Accordingly, the case study shows the EU has considerable deficiencies in managing CSDP missions and that the CFSP still suffers 
from a capability-expectations gap. This allows the conclusion that the EU still did not acquire the capabilities nor possesses the know-how to successfully implement CSDP missions. As such, the EULEX mission does not demonstrate the EU's relevance in crisis management for post-conflict situations.

\section{BIBLIOGRAPHY}

Baussner, Kurt and Enver Ferhatovič (2008): The CSDP in Action: The View from the Consumer Side. In Micheal Merlingen and Rasa Ostrauskaité (eds.): European Security and Defence Policy: An Implementation Perspective. New York: Routledge.

Breuer, Fabian (2012): Sociological Institutionalism, Socialization and the Brusselisation of CSDP: In Xymena Kurowska and Fabian Breuer: Explaining the EU's Common Security and Defence Policy: Theory in Action. UK: Palgrave Macmillan.

Cohen, Louis and Lawrence Manion (1994): Research Methods in Education. Fourth Edition. London: Routledge.

Creswell, W. John (2003): Research Design: Qualitative, Quantitative and Mixed Methods Approaches. Second Edition. London: Sage.

Cameron, Fraser (2007): An Introduction to European Foreign Policy. New York: Routledge.

Costa, Olivier and Nathalie Brack (2014): How the EU Really Works. England: Ashgate Publishing Limited.

Capussela, L. Andrea (2015): State Building in Kosovo: Democracy, Corruption and the EU in the Balkans. Prishtinë: Koha.

Dari, Elisa, Megan Price, Jens Van Der Wal, Marlene Gottwald and Nicole Koenig (2012): CSDP Missions and Operations: Lessons Learned Processes. Belgium, European Union.

Dyson, Tom and Theodore Konstadinides (2013): European Defence Cooperation in EU Law and IR Theory. New York: Palgrave Macmillan.

Dyson, Tom (2016): Neoclasical Realism: Clarifying the Nature and Role of the Systemic-and domestic-level Variables in CSDP. In Lorenzo Cladi and Andrea Locatelli: International Relations Theory and European Security: We Thought We Knew. New York: Routledge.

Gerring, John (2007): Case Study Research: Principles and Practices. New York: Cambridge University Press.

Ginsberg, H. Roy and Susana H. Penksa (2012): The European Union in Global Security: The Politics of Impact. UK: Palgrave MacMillan.

Hill, Christopher (1993): The Capability-Expectations Gap, or Conceptualizing Europe's International Role. Journal of Common Market Studies 31 (3): 305328.

Jacek, Czaputowicz (2014): European Cooperation in the Field of Security and Defence: International Relation Theories Perspective. Securitologia 1/2014: $105-115$.

Kurowska, Xymena (2008): The Role of the ESDP Operations. In Michael Merlingen 
and Rasa Ostrauskaité (eds.): European Security and Defence Policy: An Implementation Perspective. New York: Routledge.

Kaunert, Christian and Kamil Zwolski (2013): The EU as a Global Security Actor: Comprehensive Analysis beyond CFSP and JHA. UK: Palgrave MacMillan.

Larivé, H. A. Maxime (2014): Debating European Security and Defence Policy: Understanding the Complexity. England: Ashgate Publishing Limited.

Malcolm, Noel (1998): Kosovo: A Short History. New York: NYU Press.

Merlingen, Michael and Rasa Ostrauskaité (eds.) (2008): European Security and Defence Policy: An Implementation Perspective. New York: Routledge.

Mahncke, Dieter (2001): Reform of the CFSP: from Maastricht to Amsterdam. In Jörg Monar and Wolfgang Wessels (eds): The European Union after the Treaty of Amsterdam. Great Britain: Biddles Ltd, Guildford and King's Lynn.

Prezelj, Iztok (2005): Nacionalni sistemi kriznega menedžmenta. Ljubljana: Slovenia. Marginalija.

Schmitt, J. Oliver (2012): Kosova: Histori e shkurtër e një treve qendrore ballkanike. Prishtinë, Kosovë. KOHA.

Shepherd, J. K. Alistair (2015): The European Security Continuum and the EU as an International Security Provider, Global Society 29 (2): 156-174.

Toje, Asle (2010): The European Union as a Small Power: After the Post-Cold War. UK: Palgrave Macmillan.

Tardy, Thierry (2015): CSDP in Action: What Contribution to International Security. EU institute for Security Studies. France: Conde sur Noireau.

Zupančič, Rok and Nina Pejič (2018): Limits to the European Union's Normative Power in a Post-conflict Society: EULEX and Peacebuilding in Kosovo. Switzerland: Springer Briefs in Population Studies.

Zupančič, Rok, Nina Pejič, Blaž Grilj and Annemarie Peen Rodt (2018): The European Union Rule of law Mission in Kosovo: An Effective Conflict Prevention and Peace-Building Mission? Journal of Balkan and Near Eastern Studies 20 (6): 599-617.

\section{SOURCES}

Bajrami, Selvije (2011): The Rule of Law in Kosovo: Mission Impossible? Accessible at https://balkaninsight.com/2011/11/17/the-rule-of-law-in-kosovo-missionimpossible/, 8. 11. 2020.

Bytyçi, Fatos (2011): Kosovo war crimes witness found dead in Germany. Accessible at https://www.reuters.com/article/us-kosovo-war-crimes/kosovo-war-crimeswitness-found-dead-in-germany-idUSTRE78R5O320110928, 8. 11. 2020.

Bytyçi, Fatos (2018): EU justice mission leaves Kosovo, accused of failing its mandate. Accessible at https://www.reuters.com/article/us-kosovo-eu-justice/eu-justice-mission-leaves-kosovo-accused-of-failing-its-mandate-idUSKBN1JA1WH, 8. 11. 2020.

Council of the European Union (2003): European Security Strategy. Accessible at https://www.consilium.europa.eu/media/30823/qc7809568enc.pdf, 8. 11. 2020.

Council of the European Union (2016): Stabilisation and Association Agreement (SAA) between the European Union and Kosovo. Accessible at https://www. 
consilium.europa.eu/en/press/press-releases/2015/10/27/kosovo-eu-stabilisation-association-agreement/, 8. 11. 2020.

Bilefsky, Dan (2008): Kosovo declares its dependence from Serbia. The New York Times. Accessible at https://www.nytimes.com/2008/02/18/world/europe/18 kosovo.html, 8. 11. 2020.

European Union (2009): Lisbon Treaty. Accessible at http://publications.europa. eu/resource/cellar/688a7a98-3110-4ffe-a6b3-8972d8445325.0007.01/DOC_19, 8. 11. 2020.

European Commission (2014): Report from the Commission to the European Parliament and the Council: Second report on progress by Kosovo* in fulfilling the requirements of the visa liberalisation roadmap. Accessible at https://eurlex.europa.eu/legal-content/EN/TXT/PDF/?uri=CELEX:52014SC0251\&from=en, p. 15, para 7, sub-para. 7. 1, 8. 11. 2020.

European Commission (2018): Final commission staff working document: Kosovo 2018 Report. Accessible at https://ec.europa.eu/neighbourhood-enlargement/ sites/near/files/20180417-kosovo-report.pdf, 8. 11. 2020.

European Commission (2020): European Neighbourhood Policy and Enlargement Negotiations: Kosovo. Accessible at https://ec.europa.eu/neighbourhood-enl argement/countries/detailed-country-information/kosovo_en, 8. 11. 2020.

European External Action Service (2018): Military and civilian missions and operations. Accessible at https://eeas.europa.eu/headquarters/headquarters-homepage/430/military-and-civilian-missions-and-operations_en, 8. 11. 2020.

EULEX (2018): Support to the EU-facilitated dialogue between Prishtina and Belgrade. Accessible at https://www.eulex-kosovo.eu/?page=2,46, 8. 11. 2020.

House of Lords (2014): Submission in the European Union Committee on EULEX. Accessible at https://www.parliament.uk/documents/lords-committees/eu-subcom-c/cwm/CwMsubC1Dec13-4Jun14-.pdf!docid=2183313!.pdf, 8. 11. 2020.

Kosovo Law Institute (2018): Political interferences in the politicized prosecutorial system, alarm for the need of vetting in the police, prosecution and courts: Policy analysis after political interferences and public threats against Special Prosecutor Elez Blakaj. Accessible at https://kli-ks.org/wp-content/uploads /2018/09/English-Blakaj-CASE-30.08.2018-1.pdf, 8. 11. 2020.

Official Journal of the European Union (2008): Council Joint Action 2008/124/ CFSP. Accessible at https://eur-lex.europa.eu/legal-content/EN/TXT/PDF/?uri= CELEX:32008E0124\&from=EN, 8. 11. 2020.

Palokaj, Augustin (2010): EU Mission in Kosovo shows it means business. Euobserver. Accessible at https://euobserver.com/news/30116, 8. 11. 2020.

UNDP (2013): Public pulse report 6. Accessible at https://www.undp.org/content/ dam/kosovo/docs/Procurement/PPR6_Anglisht.pdf, 8. 11. 2020.

Venner, Mary (2012): The EU in Kosovo: Operational Dilemmas, Political Priorities and the Realities of Post-Conflict Assistance. Australian and New Zealand Journal of European Studies 4 (1). Accessible at https://esaanz.org.au/wp-content/ uploads/2018/01/02.-EU-in-Kosovo-VENNER.pdf, 8. 11. 2020. 